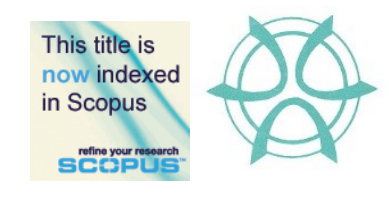

PLANNING MALAYSIA:

Journal of the Malaysian Institute of Planners

VOLUME 19 ISSUE 5 (2021), Page 180 - 191

\title{
ISSUES FACED BY TENANTS IN HIGH-RISE STRATA \\ RESIDENTIAL: CASE STUDY OF KLANG VALLEY
}

\author{
Noor Suzilawati Rabe ${ }^{1}$, Mariana Mohamed Osman², Muhammad Faris \\ Abdullah $^{3}$, Zakiah Ponrahono $^{4}$, Izlan Fitri Abdul Aziz ${ }^{5}$ \\ ${ }^{1,2,3,5}$ Department of Urban and Regional Planning, \\ Kuliyyah of Architecture and Environmental Design \\ UNIVERSITI ISLAM ANTARABANGSA MALAYSIA \\ ${ }^{4}$ Department of Environmental Management, \\ Faculty of Environmental Studies \\ UNIVERSITI PUTRA MALAYSIA
}

\begin{abstract}
Recently, demand for high-rise residential has increased every year and shifted residential development patterns from vertical to horizontal development. Living in high-rise residential will require residents to share common facilities and resources. For that, a management body is known as Management Corporation (MC) or Joint Management Body (JMB) is established. This management body is responsible to collect the service charge from residents, as well as managing and maintaining the buildings and common property. However, a review of the literature has found out gaps between the MC responsibility and residents' satisfaction. Driven by study objectives, this study focuses on exploring issues faced by the tenants living in the selected high-rise strata housing. Through a questionnaire survey, responses are randomly collected and analysed. A descriptive table, Relative Importance Index (RII) and correlation test are used in the analysis to provide findings for the study.
\end{abstract}

Keywords: High-rise strata, JMB, MC, common facilities

\footnotetext{
${ }^{1}$ Asst. Prof at IIUM. Email: suzilawati@iium.edu.my
} 
PLANNING MALAYSIA

Journal of the Malaysia Institute of Planners (2021)

\section{INTRODUCTION}

Living in stratified properties is becoming a common lifestyle especially in a major urban area in Malaysia. Recently, demand for high-rise residential buildings has increased annually due to land scarcity for the development of landed property in urban areas especially Penang, Kuala Lumpur, Selangor and Johor Bahru. The construction of high-rise buildings or also known as strata development is seen to address the scarcity of land in addition to rapid development and increased demand for housing.

In general, a strata building consists of a building divided into parcels consisting of the accessory parcel and a provisional block (if any), and everything else is considered common property such as corridors, lifts, external walls, open space, and water tanks. According to Section 4 of the Strata Titles Act 1985 (Act 318) and Section 2 of the Strata Management Act 2013 (Act 757) interpret a simple definition of common property as a piece of land in the strata that is owned by two or more owners of parcels and that does not include any specific subdivision of parcels. It also can simply define as a single property within a larger integrated development that shares the same facilities. To keep the building and facilities well-maintained, the residents are required to pay for a service charge as a fee while the Management Corporation (MC) is appointed to be responsible for managing the facilities provided. This is to ensure efficient management of strata properties which will contribute towards sustainable development. However, reviews of the literature have found out gaps between the MC management responsibility and residents' satisfaction. This paper will address and analyse the issues faced by tenants living in strata property in Klang Valley.

\section{HIGH-RISE STRATA DEVELOPMENT IN MALAYSIA}

The term 'strata' was first introduced legally in 1985 in response to the massive growth of multi-storey buildings due to rapid urbanisation in major Malaysian cities. However, only after the amendment of the Strata Management Act 2013 (Act 757) in 2015, the strata get a great deal of attention. Reena Kaur Bhatt (2018) describes the term 'strata properties' as a development or housing scheme that have a different lot or is referred to as parcels that are carved out of the building or land. In the other words, strata properties include such as flats, condominiums, townhouses as well as landed homes in gated and guarded (G\&G) neighbourhoods are included in residential strata properties. The Strata Titles Act 1985 (Act 318) sets out the framework that determined the ownership of the parcel including the airspace. It also specifies the upkeep of the shared facilities or known as the common property. The Building and Common Property (Maintenance and Management) Act 2007 (Act 663) was enacted to provide for the proper upkeep of the common property in all the strata properties. According 
Noor Suzilawati Rabe, Mariana Mohamed Osman, Muhammad Faris Abdullah, Zakiah Ponrahono, Izlan Fitri Abdul Aziz

Issues Faced by Tenants in High-Rise Strata Residential: Case Study of Klang Valley

to Section 2 of Act 663 , "common property" in the strata development area is related to the structural elements of the building. Besides, it also includes the exterior of all common parts of the building as well as all other facilities and installations and any part of the land used or capable of being used or enjoyed together by all the residents of the building. In relating to the right of common property, all the individuals or proprietors have rights and obligations in common with all other users or proprietors to use and maintain the property.

In referring to the statutory definition of common property (Act 663, Section 2), 'common property' is defined as the development area as is not comprised in any parcel, including;

- the structural elements of the building;

- stairs, stairways and fire escapes;

- entrances and exits, corridors and lobbies;

- fixtures and fittings;

- lifts;

- refuse chutes and refuse bins;

- compounds;

- drains, water tanks, sewers, pipes, wires, cables and ducts that serve more than one parcel;

- the exterior of all common parts of the building;

- playing fields and recreational areas;

- driveways, car parks and parking areas;

- open spaces, landscape areas;

- walls and fences;

- all other facilities and installations; and

- any part of the land used or capable of being used or enjoyed in common by all the occupiers of the building.

Under the Strata Titles Act 1985 (Act 318) gives the framework for forming up the Management Corporation (MC) to undertake and manage the strata scheme. Before the establishment of Management Corporation (MC), Joint Management Body (JMB) will be set up acting as an interim body to operate from the time the developer has delivered the vacant property to the buyers. Based on the amendment of the Strata Title Act 1985 in 2007, it stipulates that the MC can only be formed after 25 per cent of aggregate share units transferred either after the Joint Management Body (JMB) period if without strata titles or after the developer period if strata title was issued.

The formation of a Management Corporation (MC) is required in all strata schemes. The MC is a body formed by a committee board consisting of owners or owners of strata units. The MC plays a significant function to manage strata schemes properties in Malaysia, under the Commissioner of Building (COB) as stipulated in Act 318 and Act 757. For parcel owners and common 
property, the $\mathrm{MC}$ is responsible to oversee the funding, upkeeping, and management. The $\mathrm{MC}$ consisting of the owner of the parcel is also responsible to ensure that all the facilities are repaired in good and operable condition. In terms of maintenance and management of the strata property, the general powers of $\mathrm{MC}$ and JMB are set out in Section 21(2) of Act 757 which includes collecting charges and contributions to the sinking fund from parcel owners based on the allocated share units, carrying out maintenance and management of the buildings and to recover any cum expended by the JMB from parcel owners.

An individual includes a normal person, corporation, or other such entity according to the relevant law is referred to as 'tenants'. The satisfaction of the tenant has become a key concern in the housing market. The modernization of housing trends has several aspects that drive the needs and alternatives of residents and have a large impact on how they are satisfied (Khalfan \& Haq, 2019). Based on Gibler et al., (2014), tenants are customers who like to receive additional rental services at the cost they pay. Due to additional fees for transactions, satisfied tenants are less interested in changing their houses except for the time they are looking for and relocating to a new home. Jiboye (2009) declared that the housing satisfaction of the tenants varies and is affected by housing, the surroundings and the management systems.

As shown in Table 1, a growing number of transactions on high-rise residential property development especial for Kuala Lumpur and Selangor indicate that a higher demand for that kind of properties development. Moreover, Figure 2 shows statistics on the increasing number of high-rise developments with their average price in Kuala Lumpur.

Table 1: Residential Property Transactions by Type in Major States Q1 2020

\begin{tabular}{|c|c|c|c|c|c|}
\hline \multirow{2}{*}{$\begin{array}{l}\text { Residential } \\
\text { Property }\end{array}$} & \multicolumn{5}{|c|}{ Major States (units) } \\
\hline & $\begin{array}{l}\text { WP Kuala } \\
\text { Lumpur }\end{array}$ & Selangor & Johor & $\begin{array}{l}\text { Pulau } \\
\text { Pinang }\end{array}$ & Perak \\
\hline Terrace & 383 & 4974 & 3221 & 766 & 2320 \\
\hline Condo/ Apt & 1,317 & 1907 & 433 & 417 & 159 \\
\hline Semi-D & 48 & 696 & 417 & 244 & 352 \\
\hline Detached & 66 & 447 & 260 & 126 & 478 \\
\hline Low-cost & 310 & 2545 & 879 & 593 & 570 \\
\hline Vacant Plot & 34 & 611 & 1195 & 76 & 1312 \\
\hline Others & 263 & 1022 & 299 & 526 & 153 \\
\hline
\end{tabular}

(Source: REHDA Institute, 2020) 
Noor Suzilawati Rabe, Mariana Mohamed Osman, Muhammad Faris Abdullah, Zakiah Ponrahono, Izlan Fitri Abdul Aziz

Issues Faced by Tenants in High-Rise Strata Residential: Case Study of Klang Valley

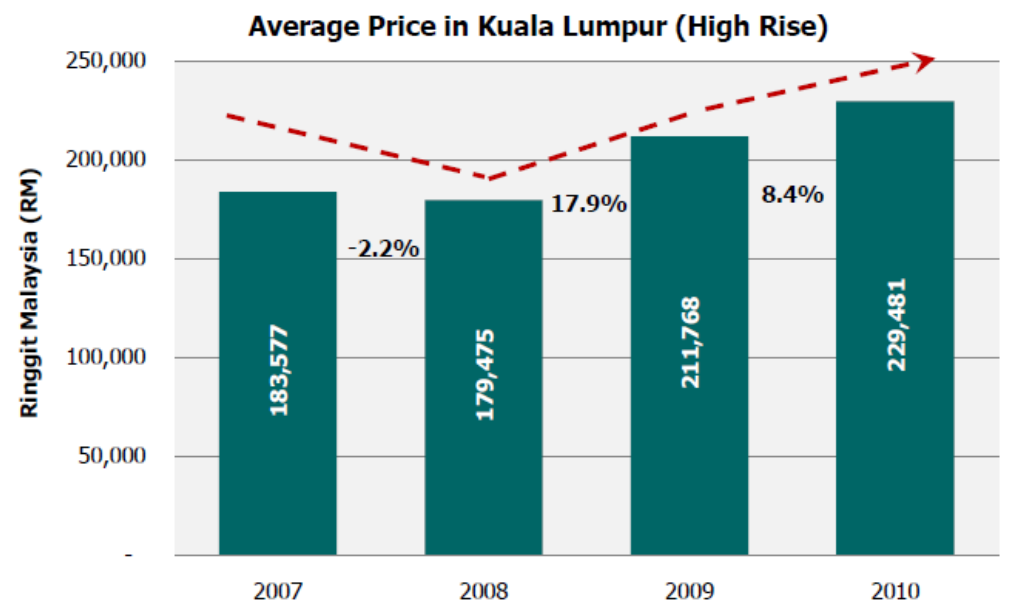

Figure 2: No of high rise residential units sold with average price in Kuala Lumpur (Source: REHDA Institute, 2011)

Among the reasons why people choose to stay in a vertical residential area is the facilities and services served for the residents are commonly within the house area. Several studies (Nor Amira Abdul Samad et al., 2018; Isma Haniza Fakhrudin et al., 2011; Tawil et al., 2010) indicate that preferences to living in high-rise property are varied, from lifestyle by the current living trend to having more opportunities for the residents to enjoy complete common facilities and for future investment. Thus, a responsible management body and ownership structure are essential to create a quality living experience for the residents and ensure that all strata properties are maintained (Tiun, 2009). 
PLANNING MALAYSIA

Journal of the Malaysia Institute of Planners (2021)

\section{RESEARCH METHODOLOGY}

For this study, the methods used are quantitative and qualitative research. For qualitative research, a review of literature, journals, published data from various secondary sources was employed. Driven by the objective formulated based on qualitative analysis, a quantitative method is used to answer the research question.

Population living in strata scheme in Klang Valley under the jurisdiction of the local authority of Selayang Municipal Council (MPS) was selected as the sampling for this study. The selection of the study area was based on the fact that the development of the high-rise residential is highly concentrated in the area. Since the data collection was planned during the pandemic and Movement Control Order (MCO), the strata residential in the study area was randomly selected based on the agreement by the $\mathrm{MC}$ to assist in data collection. The questionnaire was distributed through MC to the target population while site inventory was done by the researcher during the collection of the survey form. Due to the low number of participations from the target population, a convenient sampling method was applied that is based on the availability and willingness of respondents. Overall, 400 samples were targeted for the preliminary stage of data collection, however, the study only managed to get 100 responses.

For the data analysis, several methods including descriptive analysis by using frequency and percentage tables are presented in this paper. Besides, the Relative Importance Index (RII) was also done to present analysis related to respondents' satisfaction with facilities and damages that happen in their residential area. In addition, inferential analysis using the Spearman Rho was also conducted to explore the relationship between respondents' socio-economic background with their level of satisfaction.

\section{FINDINGS AND ANALYSIS}

Respond from 100 respondents were analysed in this study. Table 2 shows the socio-economic background of respondents involved in the study. 
Noor Suzilawati Rabe, Mariana Mohamed Osman, Muhammad Faris Abdullah, Zakiah Ponrahono, Izlan Fitri Abdul Aziz

Issues Faced by Tenants in High-Rise Strata Residential: Case Study of Klang Valley

\section{Respondents' Background}

Table 2: Summary of Respondents' Background

\begin{tabular}{|c|c|c|}
\hline Variables & Components & Percentage (\%) \\
\hline Gender & $\begin{array}{l}\text { Male } \\
\text { Female }\end{array}$ & $\begin{array}{l}60 \\
40\end{array}$ \\
\hline Age & $\begin{array}{l}21-40 \text { years old } \\
41 \text { - } 60 \text { years old } \\
\text { Above } 61 \text { years old }\end{array}$ & $\begin{array}{c}80 \\
18 \\
2 \\
\end{array}$ \\
\hline Race & $\begin{array}{l}\text { Malay } \\
\text { Chinese } \\
\text { Indian }\end{array}$ & $\begin{array}{c}96 \\
0 \\
4\end{array}$ \\
\hline Marital status & $\begin{array}{l}\text { Single } \\
\text { Married }\end{array}$ & $\begin{array}{c}8 \\
92 \\
92\end{array}$ \\
\hline Education level & $\begin{array}{l}\text { Degree } \\
\text { Diploma } \\
\text { Certificate } \\
\text { SPM }\end{array}$ & $\begin{array}{l}10 \\
12 \\
28 \\
50\end{array}$ \\
\hline No. of Household & $\begin{array}{l}1-3 \\
4-6 \\
7-9 \\
10 \text { and above }\end{array}$ & $\begin{array}{l}14 \\
44 \\
30 \\
12 \\
\end{array}$ \\
\hline Employment Sector & $\begin{array}{l}\text { Government (Regular) } \\
\text { Government (Contract) } \\
\text { Private (Regular) } \\
\text { Private (Contract) } \\
\text { Self-employed } \\
\text { Unemployed }\end{array}$ & $\begin{array}{c}6 \\
6 \\
32 \\
16 \\
36 \\
4\end{array}$ \\
\hline Monthly income & $\begin{array}{l}<\text { RM1000 } \\
\text { RM1001 - RM1500 } \\
\text { RM1500 - RM2000 } \\
\text { RM2001 - RM2500 } \\
\text { RM2501 > }\end{array}$ & $\begin{array}{c}4 \\
38 \\
28 \\
16 \\
14\end{array}$ \\
\hline
\end{tabular}

Source: Field Survey, 2021.

\section{Condition of Common Facilities Provided}

A question related to respondents' satisfaction with the provision of common facilities in their residential area was stated in the survey form. Responses based on a rating scale of 1 very unsatisfied and 4 very satisfied are used then the Relative Importance Index (RII) for each facility are calculated based on respondents' scale of preferences in the survey form. The result of RII is presented in Table 3 below. 
Table 3: RII result on Satisfaction level on common facilities provided

\begin{tabular}{|l|c|c|}
\hline \multicolumn{1}{|c|}{ Common Facilities } & RII $=\mathbf{\Sigma W} /\left(\mathbf{A}^{*} \mathbf{N}\right)$ & Rank \\
\hline Surau & 0.72 & 1 \\
\hline Mailbox & 0.685 & 2 \\
\hline Dumpster & 0.68 & 3 \\
\hline Landscape & 0.67 & 4 \\
\hline Playground & 0.56 & 5 \\
\hline Stairs & 0.56 & 5 \\
\hline Parking Space & 0.555 & 6 \\
\hline Open Space & 0.55 & 7 \\
\hline Fence & 0.52 & 8 \\
\hline Main Pipe Tank & 0.51 & 9 \\
\hline Multipurpose Hall & 0.44 & 10 \\
\hline Lift & 0.415 & 11 \\
\hline
\end{tabular}

12 common facilities are identified to be provided in the study areas. From the result, the highest RII score ranked as first is 0.72 on satisfaction towards the condition of Surau, followed with second highest is mailbox condition (RII 0.685) and dumpster ranked as third (RII 0.68). Playground and stairs shared the same fifth rank with an RII score of 0.56 respectively. On contrarily, respondents claimed they were dissatisfied with the condition of lift that based on RII score is ranked as the last rank with a score of 0.415 . Based on an interview with several respondents, the conditions of common facilities that were provided in their residential areas were different based on maintenance and management practice.

Types of damages often reported by a tenant living in high-rise strata property are identified from various literature reviews. The damages are listed in the questionnaire survey and respondents were asked to rate based on their agreement that damages often happen with a scale of $1=$ totally disagreed, $2=$ disagreed, $3=$ agreed, $4=$ totally agreed. The result of the survey is presented in Table 4 below.

Table 4: RII result on types of damages often happen in the residential property

\begin{tabular}{|l|c|c|}
\hline \multicolumn{1}{|c|}{ Types of damages } & RII $=\boldsymbol{\Sigma} \mathbf{W} /\left(\mathbf{A}^{* \mathbf{N}}\right)$ & Rank \\
\hline Vandalism & 0.91 & 1 \\
\hline Water tank leaking & 0.905 & 2 \\
\hline Pipes leaking / clogged & 0.9 & 3 \\
\hline Surau / hall damaged & 0.89 & 4 \\
\hline Roof leaking & 0.89 & 4 \\
\hline Manhole clogged & 0.885 & 5 \\
\hline Garbage house poor maintenance & 0.875 & 6 \\
\hline
\end{tabular}


Noor Suzilawati Rabe, Mariana Mohamed Osman, Muhammad Faris Abdullah, Zakiah Ponrahono, Izlan Fitri Abdul Aziz

Issues Faced by Tenants in High-Rise Strata Residential: Case Study of Klang Valley

\begin{tabular}{|l|c|c|}
\hline Gutter / rainwater pipe down clogged & 0.86 & 7 \\
\hline Playground damaged beyond repair & 0.86 & 7 \\
\hline Apron / drainage clogged & 0.855 & 8 \\
\hline Retaining wall crack & 0.855 & 8 \\
\hline Floor / wall leaking & 0.84 & 9 \\
\hline \multicolumn{2}{|c|}{ Source: Author's Calculation, 2021. }
\end{tabular}

Table 5: Spearman test between types of damages often happen in the respondents' residential property with socio-demogarphic background

\begin{tabular}{|c|c|c|c|c|c|c|}
\hline \multicolumn{7}{|c|}{ Correlation Coefficient (CC) } \\
\hline \multirow[b]{2}{*}{ Types of damages } & \multicolumn{2}{|c|}{ Age } & \multicolumn{2}{|c|}{ Monthly Income } & \multicolumn{2}{|c|}{ No. of Household } \\
\hline & $\begin{array}{c}\text { CC } \\
\text { Value }\end{array}$ & p-Value & $\begin{array}{c}\text { CC } \\
\text { Value }\end{array}$ & p-Value & $\begin{array}{c}\text { CC } \\
\text { Value }\end{array}$ & p-Value \\
\hline Vandalism & $-0.550 * *$ & 0.000 & -0.191 & 0.057 & $-0.284 * *$ & 0.004 \\
\hline Water tank leaking & $-0.521 * *$ & 0.000 & -0.191 & 0.057 & -0.145 & 0.150 \\
\hline Pipes leaking / clogged & $-0.491 * *$ & 0.000 & $-0.273 * *$ & 0.006 & $-0.317 * *$ & 0.001 \\
\hline Surau / hall damaged & $-0.569 * *$ & 0.000 & -0.173 & 0.084 & $-0.259 * *$ & 0.009 \\
\hline Roof leaking & $-0.446^{* *}$ & 0.000 & $-0.209 *$ & 0.037 & $-0.331 * *$ & 0.001 \\
\hline Manhole clogged & $-0.450 * *$ & 0.000 & -0.098 & 0.332 & $-0.308 * *$ & 0.002 \\
\hline $\begin{array}{l}\text { Garbage house poor } \\
\text { maintenance }\end{array}$ & $-0.485 * *$ & 0.000 & $-0.206^{*}$ & 0.040 & $-0.278 * *$ & 0.005 \\
\hline $\begin{array}{l}\text { Gutter / rainwater pipe } \\
\text { down clogged }\end{array}$ & $-0.396 * *$ & 0.000 & $-0.202 *$ & 0.046 & $-0.242 *$ & 0.016 \\
\hline $\begin{array}{l}\text { Damage of Playground } \\
\text { equipment }\end{array}$ & $-0.293 * *$ & 0.003 & $-0.206^{*}$ & 0.039 & $-0.295 * *$ & 0.003 \\
\hline $\begin{array}{l}\text { Apron / drainage } \\
\text { clogged }\end{array}$ & $-0.321 * *$ & 0.001 & $-0.273 * *$ & 0.006 & $-0.276 * *$ & 0.006 \\
\hline Retaining wall crack & $-0.321 * *$ & 0.001 & 0.047 & 0.645 & $-0.223^{*}$ & 0.026 \\
\hline Floor / wall leaking & $0.0252 *$ & 0.012 & 0.098 & 0.332 & $-0.306^{* *}$ & 0.002 \\
\hline
\end{tabular}

Note: $\mathrm{CC}=$ Correlation Coefficient

** \&* Correlation is significant at the 0.01 level (2-tailed).

The result of the Spearman test on the type of damages often reported by a tenant living in high-rise strata property against their background is tested. As shown in Table 5 above, since all p-values for types of damages with variables age are less than 0.05 , thus the null hypothesis can be rejected, similar to the result for variables number of households. However, only several results for variables monthly income that tested has a p-value with less than 0.05 . Overall, all significant results indicate there is a negative relationship between the variables that show as an increase in age, monthly income and number of households, increase the agreement towards claimed damages to often happen in the residential property. 
Respondents were also asked about their satisfaction on overall living condition in the strata residential property. Their responses are tested against their socio-demogrpahic background and the result is recorded in Table 6.

Table 6: Spearman test between respondents' satisfaction on with socio-demogarphic background

\begin{tabular}{|c|c|c|c|c|c|c|}
\hline \multicolumn{7}{|c|}{ Correlation Coefficient (CC) } \\
\hline \multirow[b]{2}{*}{$\begin{array}{c}\text { Level of Satisfaction } \\
\text { on overall living } \\
\text { condition in the } \\
\text { strata residential } \\
\text { property }\end{array}$} & \multicolumn{2}{|c|}{ Age } & \multicolumn{2}{|c|}{ Monthly Income } & \multicolumn{2}{|c|}{ No. of Household } \\
\hline & $\begin{array}{c}\text { CC } \\
\text { Value }\end{array}$ & p-Value & $\begin{array}{c}\text { CC } \\
\text { Value }\end{array}$ & p-Value & $\begin{array}{c}\mathrm{CC} \\
\text { Value }\end{array}$ & p-Value \\
\hline $\begin{array}{l}\text { Condition of the } \\
\text { dwelling }\end{array}$ & $-0.317 * *$ & 0.001 & 0.067 & 0.510 & $0.269 * *$ & 0.007 \\
\hline $\begin{array}{l}\text { Relationship with } \\
\text { homeowners. }\end{array}$ & -0.080 & 0.430 & 0.277 & 0.100 & 0.005 & 0.100 \\
\hline $\begin{array}{l}\text { Safety of the } \\
\text { neighbourhood }\end{array}$ & $-0.292 * *$ & 0.003 & -0.147 & 0.145 & 0.129 & 0.201 \\
\hline Safety of the residence & $-0.657 * *$ & 0.000 & -0.036 & 0.724 & -0.113 & 0.262 \\
\hline
\end{tabular}

The result in Table 6 indicates that there is no relationship between the monthly income variable with all items of overall living condition in the strata residential property as all the $p$-Values are more than 0.05 . However, the result in the table shows that the null-hypothesis of no relationship between variables can be rejected since the p-value are less than 0.05 for age variable with 'condition of the dwelling' ( $p$-value $=0.001$ ), 'safety of the neighbourhood' ( $p$ value $=0.003$ ) and 'safety of the residence' ( $p$-value $=0.000$ ). In addition, the correlation coefficient of the tests shows there is a negative relationship between the variables. The negative relationship indicates that respondents with older age are more dissatisfied with the conditions of the condition of the dwelling ( $\mathrm{cc}=$ $\left..317^{* *}\right)$, the safety of the neighbourhood $(\mathrm{cc}=-.292 * *)$ and safety of the residence $\left(\mathrm{cc}=-.657^{* *}\right)$. On the other hand, since the $\mathrm{p}$-value is less than 0.05 for households' number variable with 'condition of the dwelling' thus the null hypothesis can be rejected. The result also shows there is a positive relationship $\left(\mathrm{cc}=.269^{* *}\right)$ that implies the higher the number of households, the more the satisfaction level on the condition of their dwelling. 
Noor Suzilawati Rabe, Mariana Mohamed Osman, Muhammad Faris Abdullah, Zakiah Ponrahono, Izlan Fitri Abdul Aziz

Issues Faced by Tenants in High-Rise Strata Residential: Case Study of Klang Valley

\section{CONCLUSION}

Respondents who participated in this study were coming from various socioeconomic backgrounds with a majority of $80 \%$ aged between $21-40$ years old. $92 \%$ of them were married and $30 \%$ earned more than RM2000 income a month. From the RII result, the study found out that the majority of the respondents claimed they were satisfied with the condition of surau while least satisfied with the condition of lift. About types of damages often happen in the residential property, the RII result revealed that most respondents claimed vandalism and water tank leaking are kinds of damages that often happen. Meanwhile, the least damages rarely happen was the floor or wall leaking. This study finding reveals that there are various damages often reported happened in the highrise strata property that concerns the safety of the property dwelling. Under the Strata Management Act 2013, a homeowner has the right to report and negotiate a solution with the MC or JMB.

In addition, the Spearman rho test conducted shows that an increase in age, monthly income and number of households, increases the agreement towards claimed damages to often happen in the residential property. The test also indicates the higher the number of households, the more the satisfaction level on the condition of their dwelling. Moreover, the negative relationship from the result indicates that respondents with older age are more dissatisfied with the conditions of the condition of the dwelling, the safety of the neighbourhood and the safety of the residence.

Often, small damage can lead to other larger problems within the building. For highrise strata property, it is the responsibility of MC to deal with common building defects to avoid serious accidents, emergency evacuations and in the worst-case scenario loss of life and property. Hence, parcel owners and management committee members need to be more aware of their duties and rights when it comes to managing and maintaining common property.

As the development of strata properties has become widespread in Malaysia, there is a need to lay out strict enforcement by the authority such as the Commissioner of Building (COB) and compliance by all parties involved to the provisions of Act 757 for the strata management to be improved. The review and amendment of the Act are also necessary to be more comprehensive and dynamic enough to cater for any issues which may occur due to the fast development.

\section{REFERENCES}

Gibler, K. M., Kananen, J. \& Tyvimaa, T. (2014). The relationship between the determinants of rental housing satisfaction and considering moving in Finland. Property Management, 32(2),104-124

Government of Malaysia. (2007). Building and Common Property (Maintenance and Management) Act 2007 (Act 663). Percetakan Nasional Malaysia Berhad 
Government of Malaysia. (2013). Strata Management Act 2013 (Act 757). Percetakan Nasional Malaysia Berhad

Government of Malaysia. (2006). Strata Titles Act 1985 (Act 318). Percetakan Nasional Malaysia Berhad

Isma Haniza Fakhrudin, Mohd Zailan Suleiman \& Roslan Talib (2011). Journal of Facilities Management, 9(3), pp. 170-180

Jiboye, A. D. (2009). Evaluating tenants' satisfaction with public housing in Lagos, Nigeria. Town Planning and Architecture, 33(4), 239-247

Khalfan, M., \& Haq, I. U. (2019). Tenants' Satisfaction in Abu Dhabi (UAE): A survey. Journal of Business, 14(1), 20-27

National Housing Policy (2017). National Housing Department, Ministry of Housing and Local Government

Reena Kaur Bhatt (2018). How to buy a house in Malaysia in 12 steps. Retrieved from iProperty: https://www.iproperty.com.my/guides/how-to-buy-a-house-inmalaysia-in 12 -steps/

REHDA Institute (2020). Residential Property Transactions by Type in Major States Q1 2020. https://rehdainstitute.com/residential-statistics/

Tawil, N. M., Che-Ani, A. I., Ramly, A., Daud, M. N., \& Abdullah, N. A. G. (2011). Service charge issue in Malaysian high-rise residential management: An analysis using a fuzzy conjoint model. International Journal of Physical Sciences, 6(3), $441-447$

Tiun T. L. (2009). Managing High Rise Residential Building in Malaysia: Where are We? In Proceedings of the 2nd NAPREC Conference, INSPEN, Bangi: INSPEN. 1-25

Received: $5^{\text {th }}$ November 2021. Accepted: $5^{\text {th }}$ December 2021 